\title{
Blogging as a Means of Professional Development for ELT Professionals
}

Praveen Kumar Yadav

\begin{abstract}
Reading and publishing articles in journals and organizing conferences, seminars and trainings are common traditional modes of professional development. For journals, they are selective in nature and restricted by money and its turn out is very slow as well. Likewise, physical space and time along with a lot of people are required to get together to organize conferences, seminars and trainings. Furthermore, such traditional modes of developing professionalism in ELT are limited in the scope, not easily accessible resources and they do not provide autonomy to the individuals. But blogging is one of the emerging professional development tools for ELT Professionals. The innovative tool is easily accessible and affordable as it is neither limited in scope nor restricted by money. The present article draws some ideas about how blogging can help, enhance and enrich English Language Teachers and Learners to develop themselves as ELT Professionals.
\end{abstract}

Key words: Computer Assisted Language Learning, Blogging, Professional development, Collaborative learning, Techniques.

\section{Introduction:}

I nformation Communication and Technology (ICT) has taken its grips over each and every sector and English language teaching and learning cannot be an exception. The use of technology in language teaching and learning is seen for many years. Before I reach the main theme of the article 'blogging as a means of professional development for ELT professionals, I would like to initiate this write-up with brief concept about Computer Assisted Language Learning (CALL) since it has brought a great revolution in the application of different technologies like computer device and internet in ELT, which is very essential for blogging in ELT.

The study of the use of computers in learning and teaching languages in the broadest sense, from the use of word processors to the use of the Internet, is known as computer-assisted language learning (CALL) (Warshauer, 1996 pp. 3-9). The CALL has been defined as "the search for and study of applications on the computer in language teaching and learning" (Levy, 1997) (as cited in Jantassova et. al, 2009, p.55). The development of CALL contributes a lot to establish the relationship between development of technology and pedagogy. Later, the CALL has rapidly shifted to Network based language learning and teaching. It has created boundless opportunities for English language teachers and learners to enhance their skills to develop themselves as professionals. However, the use of web based language learning and teaching has come so fast and overwhelmingly that a large majority of teachers in Nepal have not technologically or pedagogically prepared for this educational reform.

The studies will show how those who are involved in ELT can develop themselves as ELT professionals in an effective and innovative way. Professional development in ELT is sharing and learning new ideas about how to teach, carry out research and develop scholarship as ELT professionals through different means like journals and other print media, conferences and workshops and joining 
professional network or association like NELTA. Sharing and learning professional knowledge and skills through journals, conferences and workshop has become traditional modes in the age of communication information and technology. Unlike those traditional ones, blogging emerged as an innovative and effective means of professional development for ELT professionals in the changing context. Hence, the present write-up will mainly explore the ways or the techniques showing how blogging helps ELT practitioners to develop their professionalism in ELT.

The present article is organized into mainly three sections. The first section deals with a short introduction of blogging followed by its rationale in ELT. Then it moves along with the concept of professionalism in ELT with different views of the scholars and experts. The third section of the article draws some conclusions followed by some of the techniques of developing professionalism in ELT through blogs with instances.

\section{Blogging and its rationale in ELT}

In the most general sense, blogging means creating Weblogs on the web or Internet or cyberspace. Weblogs or blogs for short are generally like the websites that are easily created and easily updatable. The blogs look different from regular webpage. According to Webopedia, an online encyclopedia dedicated to computer technology, blog is defined as "Short for Web log, a blog is a Web page that serves as a publicly accessible personal journal for an individual. Typically updated daily, blogs often reflect the personality of the author."

Will Richardson is internationally known "evangelist" for the use of weblogs, RSS, and related Internet technologies in classrooms and schools. He puts his views about weblog,

A Weblog is an easily created, easily updatable Website that allows an author (or authors) to publish instantly to the internet from any Internet connection. The earliest blogs were literally "Web logs" or list of sites a particular author visited on any given day that would be revised by changing the HTML code and updating the file on a server. But soon, the Internet geeks who maintained these sites developed software to automate the process and allow other people to collaborate. Happily, blogging today doesn't require any knowledge of code or FTP. It takes as much skill as sending an e-mail. (Richardson, 2009, p.17)

According to Blood (2000), blogs have existed in the cyberspace community since 1998. In August of 1999 the release of Blogger, a free blog hosting service, fostered the rapid growth of blog sites. Later, blog genre extended into various professional realms especially journalism and business. The cover story of the first issue of Fortune magazine in 2005 introduces " 10 tech trends to watch in 2005 ", and blog ranks the first one. "According to blog searchengine and measurement firm Technorati", Fortune reports, "23,000 new weblogs are created every day - or about one every three seconds" (Wu., 2005, p. 6).

There are several facts that claim to have the rationale of blogging in English language learning and teaching. Teaching English language means getting updated regularly with the new and effective methods and approaches, materials and practices that can be effectively and creatively incorporated in English language teaching. And blogging provides the bloggers and readers with the updated information and best practices in the pedagogy basing on true experience, knowledge and research findings. Besides, it helps gather different people with the same nature of jobs or skills from different places of the world. It is neither restricted by money or space but easily accessible to everyone at everywhere. Moreover, the activities that the teachers carry out with a view to develop themselves as professionals can easily be carried out through blogging. Either in the classroom or in the professional association created by them, be it group discussion, collaborative learning or dealing with large number of students in a class, the blogging can be the best and effective tool to solve all the problems. It provides autonomy to both the teachers and learners. Harmer (2008) presents a range of activities for training learners to be autonomous. (as cited in Neupane, 2010, pp. 118-119). One of them is learning journals that help develop the learners' writing skills, express their feelings and provide the opportunity for the teachers to better understand their learners and monitor both what they are learning and how they are learning. Therefore, it is very important and rationale in English language pedagogy. 


\section{Professional development in ELT}

A profession simply means a type of job that requires special training, high level of knowledge and skills. Taylor (1978) defines, "A profession is an occupation that assumes responsibility for some tasks too complex to be guided by rules". For Weiler (1995), professionals are at the top of a hierarchical pyramid of occupations, they are the experts in a particular field and they rationally employ advanced knowledge for common good (as cited in Joshi, 2010, pp. 12-13).

No doubt, professional development is the ultimate goal for all those involved in different professions be it medicine or driving but we are concerned with ELT here. Professionalism in ELT does not have a long history. Regarding the history of the language teaching as a profession, Richards and Rodgers (2001, p.1) say,

Language teaching came into its own as a profession in the twentieth century. The whole foundation of contemporary language teaching was developed during the early part of the twentieth century, as applied linguists and others sought to develop principles and procedures for the design of teaching methods and materials, drawing on the developing fields of linguistics and psychology to support a succession of proposals for what were thought to be more effective and theoretically sound teaching methods. Language teaching in the twentieth century was characterized by frequent change and innovation and by the development of sometimes competing language teaching ideologies.

Similarly, Ur (2002, p. 390) claims that English language teaching has not yet reached the level of professionalism. To put it another way, English Language Teaching (ELT) is in the process of professional development in the world including Nepal.

Change is the natural phenomenon and it keeps on taking place in the society with the pace of time. In the changing time and context, new ideas and concepts, new methods, approaches and techniques in the pedagogy are emerged and developed. Even the curricula come up with new textbooks and new contexts. But the formal training, pedagogical knowledge and skills that a teacher has already acquired in the college before she steps into teaching as a profession cannot be sufficient during her professional career. To walk together with the changing time and context, she requires different learning strategies for professional development. To support the views, Pennington (1990) believes that every teacher needs professional growth throughout her career. (as cited in Gnawali, 2008, p. 219)

Academic qualifications once acquired are not enough for ever, so professional development helps teachers update themselves. Thus, it can be said as an ongoing learning process in which teachers engage voluntarily to learn how their teaching can be made effective to fulfill the learning needs of their students. The key goal of professional development is to promote effective teaching that results in learning gains for all students.

\section{Blogging as a means of professional development in ELT}

According to Gender (2000), 'Professional development includes formal experiences such as attending workshops and professional meetings and mentoring and informal experiences such as reading professional publications, watching television documentaries related to an academic discipline' (as cited in Joshi, 2010, p.9).

Unlike different traditional professional development tools like publication of journals and organizing conferences, seminars and trainings, blogging is one of the innovative means of professional development for ELT professionals since it is easily accessible and affordable. Blog is an online Web journal that can offer a resource rich multimedia environment.

Richards and Farrell (2005) identifies ten different techniques that facilitate English language teachers' professional development. They include self-monitoring, support groups, journal writing, classroom observation, teaching portfolios, analysis of critical incidents, case analysis, peer coaching, team teaching and action research. Apart from these techniques, there are several other techniques like joining professional organisation/association/network, subscribing to ELT magazines and journals and organizing different trainings, workshops, seminars and conferences and so on. These techniques focus 
on collaborative learning, an important tool that covers almost all the techniques that can be applied for the development of professionalism in ELT. However, here are some of possible, frequent and relevant techniques that can be applied using blogs.

\section{Blogging for networking people/ organisations}

Professional development requires networking or associating with the like-minded organisation. Khaniya (2006, p.7) argues that professionals form a specific group or community because of the nature of the tasks they perform. By virtue of its nature, English language teaching professionals constitute a special group of people, and have a special kind of publications like ELT journal, Young Voices in ELT; they have special organisations like IATEFL, TESOL, and NELTA.

Blogging can be the effective tool for networking or helping English language learners and teachers affiliate to the professional organisation and it has been found to be useful as well. To support the views, Poudel, et al. (2010, p.20) says, networking activities, via mailing group, website, and recently blogging and use of wiki, have become established in NELTA.

Once English language learners and teachers visit the blog with learning stuffs for professional development, they get associated with the network. The blogs started by the professional organisation or highly experienced ELT professionals help the readers, authors, bloggers and people with the like-minded thoughts and views, for instance NeltaChoutari (www.neltachoutari.wordpress. com) could be much beneficial for networking people or organisations that share similar kind of professional ideas.

On the individual or professional development's blog, sharing or linking with the web-addresses or professionalblogs of such professionalorganisation like International Association of teachers of English as a Foreign Language (IATEFL), The Association of the Teachers of English to Speakers of Other Language (TESOL), Society of Pakistan English Language Teachers (SPELT) and NELTA can establish networking among ELT personnel and professional organisations.
One of the live examples of networking through blogs is ELT Teachers' Network (http://celtathens.grou.ps/blogs retrieved on Dec 30, 2011.)

\section{Blogging for professional discussion}

Blogs have the power to create greater interaction due to their ability to archive, create immediacy in conversation and allow many to have equal voices in professional or personal discussions. (Tapscott \& Williams, 2006 as cited in Hines, 2008). Blogs can be a platform to organise and share various types of professional discussions among English language teachers. They create autonomy among the readers and the bloggers. They are easily accessible and do not require space and other infrastructure as required in the workshop, seminar, conferences.

For instance, NELTA's monthly professional blog NeltaChoutari ${ }^{1}$ has turned out to be a forum for NELTA members and those involved in English language learning and teaching for sharing their ideas with their articles and comments.

To launch the professional discussion, the bloggers can pick up some contemporary issues in ELT and share their ideas in the form of article. The readers who visit the blog go through the article and can make comments with his additional ideas, concept and views in response to the article shared for discussion. In this way, it can have a series of comments and in the meantime, the bloggers should always be noticing the comments and responding to their views with encouraging words so that others can also participate in the discussion. Thus, blogging can be a means of promoting professional discussion and dialogues among ELT practitioners.

\section{Mentoring/coaching through blogging}

Mentoring generally means coaching. It is a process by which an experienced professional teacher known as a mentor supports and assists novice or less experienced teachers known as mentees by providing required guidance, counseling, ideas and information on fulfill the professional responsibilities.

Portner (1998) says "Mentoring is a powerful and

1 NeltaChoutari www.neltachoutari.wordpess.com, professional blog of NELTA 
effective way to provide support and assistance to neophyte teachers during their first year on the job" (as quoted in Pandey, 2009). As Pandey (2009) has discussed the English teachers of Nepal are well familiar with the concept of mentoring which helps them to adjust in the new situation and cope with the problems, get new ideas of solving the problems. Therefore, it is a 'platform for new and experienced teachers to share the things, to understand the new situation' (p. 84). Although the Nepalese teachers are familiar with the concept of mentoring, they have not formally practiced mentoring in their institutions yet. It is one of the important learning strategies that can enhance professional development in ELT.

Personal or professional blogs of senior, experienced and expert teachers can be the best ways of mentoring the novice teachers with professional ideas and information, guidance and counseling. For instance, I would like to suggest the readers or teachers to visit Gautam's professional blog https://sites.google.com/site/ gangasprofessionaldevelopment/ that is enriched with sufficient information and ways how they can development professionalism with the prerequisite needed. Gautam (2011) puts his views,

I also designed a Google that I plan to use with my students back in Nepal. In this website, I have tried to include the wonderful online resources that English teachers can use in their class. Also I have hyperlinked a lot professional development resources. I will regularly update the page and please do feel free to browse the page and use the resources available there. Also, please do send me your feedback and comments so that I can make it more reader-friendly and user-friendly. (NeltaChoutari, July 2011)

Besides, there are several personal and professional blogs of different scholars, which are really helpful in mentoring and coaching English language learners and teachers.

\section{Peer Observation through blogging}

Peer observation is a powerful tool to help teachers find out about their own and their colleagues' classroom practices. The observation involves all the activities that the teachers carry out inside and out the classroom from the lesson planning, notes taking, teaching and evaluation to different learning techniques of professional development. Such activities can be shared through blogging. Besides, audio or video recording could also be done for sharing on the blog.

Peer observation through blogs is not for making criticisms, monitoring or judging colleagues' teaching skills. It may sometimes turn out to have negative experience by the teachers. However, Ur (1996, p.322) suggests a solution, "One possibility is to make a mutual arrangement with a likeminded colleague: I'll observe your lesson, you observe mine and we'll share feedback" (as cited in Adhikari, 2010, p. 26). Most importantly, it provides an opportunity to see others' teaching and trigger reflections on their own teaching as well. The tool can be used for exploring strength and weak points of the teachers. Moreover, it develops self-awareness and self-consciousness on the part of the teachers and gradually they can improve themselves and help others improve due to the tool.

\section{Self-monitoring through blogging}

Roberts (1998, p.305 as cited in Mann, 2005, p.108) argues that learning and development through teaching is only possible through a process of reflection, self-monitoring and self-evaluation. He sees these processes as 'the only possible basis for long-term change'. A process of exploration or investigation in the classroom is often a catalyst for self-evaluation, self-monitoring and reflection. Therefore, it is very necessary for English language teachers to understand themselves and their teaching methods including their strength and weaknesses if they want to develop their professionalism. It is only possible through self monitoring. After they evaluate their teaching behaviour and practices through self monitoring, they can improve themselves by fulfilling their professional requirements like special trainings and other learning strategies.

James (2001) and Richards \& Farrell (2005) provide a number of procedures for self-monitoring and self-evaluation and suggest various forms of lesson reports, checklists and questionnaire (as cited in Mann, 2005, p.108). To follow the technique 'self-monitoring through blogging', the information about one's teaching activities should 
be documented or recorded as the blog posts in order to review or evaluate teaching. Finally, the blogging provide the authors opportunity to review their documented lesson plans, questionnaire and others so that they can evaluate themselves.

\section{Teaching portfolios through blogging}

A teaching portfolio refers to a collection of documents that promote their learning and other items that provides information about different aspects of teacher's work. It is like a digital library that facilitates the teachers for professional development. Such portfolios can be developed through blogs easily, which could be referred as electronic portfolios (eportfolios in short). In their blogs, the teachers can create eportfolios by uploading the pdf documents, slide presentation, photos, audios and videos related to teaching learning activities and also by adding hyperlinks in their blogs.

Dr. Helen Barrett, who retired from the faculty of the College of Education at the University of Alaska Anchorage in 2005 and is currently doing research for a book on Interactive ePortfolios to be published by the International Society for Technology in Education, has developed the eportfolios, http:// electronicportfolios.org/, which include chapters in several books on Electronic Portfolios, Google Sites that she developed and numerous articles with the help of hyperlinks. Such eportfolios can be developed in the blog as well. Even the teachers can include teaching plans, sample of student work, feedback, achievements, photos, drawing, poems, observation, report and discussion in the eportfolios which help us to reflect on their works and provide ideas for professional development (http://electronicportfolios.org/).

\section{Teaching Journal through blogging}

A teaching journal is an ongoing written account of observations, reflections, and other thoughts about teaching. Such journal can be developed either in the form of a notebook, or electronic mode. In case of electronic mode, the journal writing can be promoted through the blogs that can serve as a source of discussion, reflection, or evaluation.

According to Udell (2001, as cited in Yang, 2009, p. 14), blogs are a "genuinely new literary/ journalism form". It enables a teacher to keep a record of classroom events and observations. The teachers can create their blogs individually or in collaboration with their colleagues for recording daily experience, learning, feelings, emotional responses and analysis of observation and teaching.

In Nepal, a professional team of NELTA members have collaboratively started publishing the monthly journal 'NeltaChoutari' through blogging.

\section{Peer Coaching through blogs}

Peer coaching is one of the professional development strategies in which teachers enhance their expertise by sharing aspects of teaching with peers, observing each other's teaching, providing feedbacks, pooling their experiences, and being mentored by an experienced peer.

According to Robbins (1991, p. 1),

Peer coaching is a confidential process through which two or more professional colleagues work together to reflect on current practices, expand, refine, and build new skills, share ideas; teach one another; conduct classroom research or solve problems in the work place. (cited in Richards and Farrell, 2005, p. 143)

Web2.0 modules in the community include Friends, Blog, Wiki, Sharing, Question, Forum, Repository, Group, Online mentorship, and Expert studio. Shuang Li, Hongtao Sun and Xun Zheng (2008) carried out a case study on design of teacher peer-coaching activities supported by a web 2.0 community basing on the project 'Experimental Study on Web-Based 'Peer coaching' Teacher Professional Developmental Model' launched by Research Center of Distance Education (RCDE) of Beijing Normal University with financial support of the Ford Foundation of United States. The project explored how peer coaching supported by Web 2.0 technologies could enhance teacher professional competency and contribute to build teacher community of practice.

English language teachers can create the blog to launch peer coaching that can be an effective way to promote professional development. It provides opportunities for two teachers or more to look at teaching problems and to develop possible solutions. 


\section{Webinar through blogging}

A presentation, lecture, workshop or seminar can be transmitted over the Web. Such web based seminar is termed as webinar. The webinar can be organized through blogs and what we need is webinar set up tool in our blog.

The webinar tool is one of the latest developments that enables to transmit video, audio and images. It creates opportunities for both educators and learners to experience different levels of interaction online. Wang and Hsu (2008, p. 177) presents the advantages of the webinar tool;

There are five advantages of using the webinar tool to facilitate communication between two sites: (1) Webinar tool is affordable (de Gara \& Boora, 2006). Users can participate in a webinar session with a computer, video/audio capture devices, and broadband network connections. (2) Webinar tool enables synchronous communication. Instructors can communicate with the learners in a synchronous format to provide immediate feedback to learners (Hotcomm, 2003). Webinar tool facilitates real-time multimedia demonstrations. Instructors can share the application on the presenter's site with all participants. (4) Webinar tool facilitates multilevel interaction. Instructors can lecture, interact with the audience, facilitate participant group collaboration in a real-time format (Marjanovic, 1999), and designate certain participants to be in charge of the sessions. (5) Webinar tool provides an environment in which participants can archive seminar content for personal review or for people who missed the real time session.

The webinar is very helpful for teachers in finding solution of pedagogical problems. It helps them in promoting a frank, friendly and healthy discussion of the common problems and finally it helps them for finding their concrete practical solutions based on discussion. Such activities do not only broaden the professional outlook of the participants but also prepare them to tackle the problems effectively.

\section{Caseanalysis and analysis of critical incidents through blogs}

Richards and Farrell (2005) take both case analysis and analysis of critical incidents for the effective techniques that facilitate professional development of teachers.

Case analysis in pedagogy includes gathering information over time about a teaching situation and understanding the situation basing on the information and deriving principles from the analysis. The analysis can be carried out through blogs in a participatory way after it is shared on the web in the form of blogs. It can explore the common problematic issues in language teaching, their analysis in a participatory way through comments and draw out best pedagogical practice. Through reading and commenting on cases, they can analyze and learn the effective practice in teaching learning activities.

Accidental and unexpected critical incidents take place during teaching and such incidents help to trigger insights about teaching. Such critical incidents can be done by posting on the blog with an appeal to make reflective comments by analyzing the incident. The blog posting of the incidents followed by a series of analytical comments will be concluded after a certain period of time.

Both case analysis and analysis of critical incidents should be carried out among the group of teachers through blogging to promote real and effective review and discussion. These analyses will certainly help teachers in professional development.

\section{Development of resource centre through blogs}

Resource centre is a collection of various documents containing information and knowledge. Development of the resource centre is one of the effective ways for professional development of English language teachers. In the support, Giri (2010, p. 68) explains, "In an ELT situation, especially where English is taught as a second or foreign language, there is often a need of an organisation, a resource centre, within a school system, ELT department or an educational network that helps with the development and use of resource materials, a venue that offers its users a wide variety of services such as providing a reference for the queries, concerns and information, and a forum which offers professional development initiatives for ELT practitioners. 
Unlike development of resource centres in physical space, the blogging helps create such centres on the web. In the comparison of those in physical space, it is easily accessible anywhere, anytime and it is not even restricted by money. For example, NeltaChoutari, professional blog of NELTA is developing as a resource centre for Nepalese English language teachers. In addition, the blogs can make use of other Internet resources for learning. Users and teachers can create more learning resources by adding hyperlinks within the blogs (Godwin-Jones, 2003 as cited in Yang, 2009, p. 14).

For examples,

http://iflaslblog.wordpress.com/ , This blog designed for the Newsletters or IFLA School Libraries and Resource Centers section

http://aasl.ala.org/aaslblog/, The official web log of American Association of School Librarians

\section{Reflective logs through blogging}

The history of blogging witnesses that people used the tool for recording the events of their life, journey and achievement before it was used for another purpose. Blogging keeps the record of all the entries including comments posted in the blog.

Luehmann (2008) argues blogging culture, in which frequent updating is expected and ideas and arguments are judged on merit (Downes, 2004), may encourage ongoing and thoughtful writing and reflection.

It is a free web space where the teachers can record a log of activities carried out do throughout their teaching learning career on daily or regular basis. Such logs do not only summarize what happened, but also reflect on those experiences and report on what they have learned. It helps educators reflect on how to improve professional practice, discover what is working and what is not and explore personal strengths and the areas of improvement. Maintaining such reflective logs on the blog ultimately helps teachers develop their professionalism.

\section{Conclusion}

Blogging is free and user-friendly and it does not require money and physical space. All you need is the computer with internet connection and blogging skills. The more sound blogging skills you, the more you can benefit.

Today blogs have become an effective platform to share personal as well as professional ideas to improve themselves through interaction with others. They are a collaborative space, as readers become a part of the writing and learning process. Yang (2009, p. 13-14) points out the following characteristics of the blogs that make them useful tools for language teaching and learning.

- Blogs can stimulate reading and motivate learning

- Community building through blogs

- Blogs provide hyperlinks to other resources

- Blogs provide a learning space

Janice (2009) suggests English language teachers that reading readily-available articles and books written by 'experts' and participating in online events or blogs with invited professionals is an alternative if 'experts' are not available in the flesh somewhere near you.

There are a number of learning activities and techniques that can be promoted through blogging as I have mentioned above in the article. However, they are linked with one another. It is the teachers whose responsibility is there to pick up the best one that suit their interests, the amount of time they spend on and the issues and the context they want to focus on.

Aforementioned techniques with the help of blogs for professional development for English language teachers largely focus on collaborative learning. They also include that the blogs helps in building networks among English language teachers and promoting professional dialogues. According to Poudel et al. (2010), networking and dialogues are two major components of professional collaboration and development in language teaching research and practice.

I am still a novice at the use of blogs for enhancing professional development. Nevertheless, a number of the articles and paper presentations related to teaching learning activities through the blogs and researches on the blogs related to ELT suggest, support and encourage ELT practioners for using 
the blogs as a means of developing professionalism in ELT. It can be a panacea for the teachers when a blog is systematically set up and the bloggers are technically sound in blogging.

\section{The Author}

Praveen Kumar Yadav works as a Development Coordinator in the Plan Nepal, Rautahat Programme Unit. Before he joined the organization, he was involved in teaching English at higher secondary and Bachelor level in Rautahat. He is presently carrying out his research on online resources for professional development. He is an executive member of NELTA Birgunj. Awareness, empowerment and advocacy for child rights, human rights based approach to the community development, and innovative ELT issues are his interests.

\section{References}

Adhikari, K. (2010). Collaborative Learning for teachers' Professional Development. Unpublished M. Ed. Thesis, Tribhuvan University, Kathmandu

Gautam, G. R. (2003). Professional organization and professional development: A ten years' journey of NELTA. Journal of NELTA, 8 (1\&2), 88-96.

Gautam, G. R. (2011). A Brief Reflection of my Humphrey Fellowship Program at Boston University. NeltaChoutari, professional blog of NELTA. Retrieved on October 20, 2011 from http:// neltachoutari.wordpress.com/2011/07/01/a-briefreflection-of-my-humphrey-fellowship-program-atboston-university/

Giri, R. (2010). English Language Teachers' Resource Centre: A Model for Developing Contexts. Journal of NELTA, 15 (1\&2), 64-76.

Gnawali, L. (2008). Teacher Development: What is it and Who is Responsible? Bodhi: An Interdisciplinary Journal. 2(1). (P. 219-223).

Hines, M. (2008). Using Blogging as a Tool to Further Teacher Professional Development. TCC Proceedings. http://etec.hawaii.edu/ proceedings/2008/Hines2008.pdf

Jantassova, D., Zhilkishenova, S. \& Klukina, E. (2009). Computer dictionaries and encyclopedia in teaching English as a second Language. Journal of NELTA, 14, 55-62.

Jenny, J. (2009). Ways to continuing professional development. Retrieved on October 20, 2011 from http://www.teachingenglish.org.uk/articles/ ways-continuing-professional-development

Joshi, D. K. (2010). Learning Strategies of English language teachers for Professional Development.
Unpublished M. Ed. Thesis, Tribhuvan University, Kathmandu.

Khaniya, T. R. (2006). Professionalism of English language teachers. Young Voices in ELT, 5, 7-10.

Li, S., Sun, H., \& Zheng, X. (2011). A Case Study on Design of Teacher Peer-Coaching Activities Supported by a Web 2.0 Community. Hybrid Learning. In R. Kwan, J. Fong, L.-f. Kwok \& J. Lam (Eds.), (Vol. 6837, pp. 40-50): Springer Berlin / Heidelberg.

Luehmann, A. L. (2008). Using Blogging in Support of Teacher Professional Identity Development: A Case Study. The Journal of the Learning Sciences, 17 (3), 287-337, doi:1080/10508400802192706

Mann, S. (2005). The language teacher's development. Language Teaching, Vol.38 (No.3). pp. 103-118. Retrieved on October 20, 2011 from http://www2.warwick.ac.uk/fac/soc/al/staff/.../ mann/mann_s/stateof.pdf.

Murugaiah, P., Azman, H. Ya'acob, A. \& Thang, S. M. (2010). Blogging in teacher professional development: Its role in building computerassisted language teaching skills.

International Journal of Education and Development using Information and Communication Technology (IJEDICT), Vol. 6, Issue 3, pp. 73-87. Retrieved on October 5, 2011 from http://20thandcontemporary. blogspot.com/2011/02/list-of-articles_14.html.

Neupane, M. (2010). Learning Autonomy: Concept and Considerations: Journal of NELTA, 15, (1\&2), 114120.

Pandey, S.B. (2009). Mentoring for Teachers' Professional Development in Nepal: A Status Study of Kathmandu District. An Unpublished M. Ed. Thesis, Kathmandu University, Dhulikhel, Kathmandu, Nepal.

Poudel et al. (2010). 'NELTA Networking: Building Connections for Professional Conversation.' NELTA Conference Proceedings, 2010. NELTA, Kathmandu.

Richards, J. C. \& Farrell, T. S. (2005). Professional development for language teachers. Cambridge: Cambridge University Press.

Richards, J. C. \& Rodgers, T. S. (2002). Approaches and Methods in language teaching. Cambridge: Cambridge University Press.

Richardson, W.(2009). Blogs, wikis, podcasts and other 
powerful web tools for classrooms. California: Corwin Press.

Sharma, B. K. (2011). Do you know why "they are "there": Professional value of personal blog. NeltaChoutari, professional blog of NELTA. Retrieved on October 20, 2011.

Ur, P. (2002). The English Teacher as Professional. Methodology in Language Teaching: An anthropology of Current Practices. Cambridge University Press, (p:389-391).

Ur, P. (1996). A Course in language teaching. Cambridge: Cambridge University Press.

Wang, S. \& Hsu, H. (2008). Use of the Webinar Tool (Elluminate) to support Training: The Effects of Webinar-Learning Implementation from StudentTrainers' Perspective', Journal of Interactive Online Learning, vol.7, no.3, pp.175-194.
Wu. W. S. (2005). Web-based English learning and teaching in Taiwan: Possibilities and Challenges. Paper presented at The First Hsiang-shan Area, Intercollegiate International Conference on English Language Teaching, Chung Hua University, Hsuan Chuang University, and Yuanpei University of Science and Technology, Hsinchu, Taiwan. Taipei: Crane Publishing. (pp.215-226). Retrieved on October 5, 2011 from http://people.chu.edu.tw/ wswu/publications/ papers/conferences/05.pdf.

Yang, S.-H. (2009). Using Blogs to Enhance Critical Reflection and Community of Practice. Educational Technology \& Society, 12 (2), 11-21. Retrieved on October 5, 2011. http://www.ifets. info/journals/12_2/2.pdf. 